medRxiv preprint doi: https://doi.org/10.1101/2021.02.06.21251214; this version posted February 9, 2021. The copyright holder for this preprint (which was not certified by peer review) is the author/funder, who has granted medRxiv a license to display the preprint in perpetuity.

It is made available under a CC-BY-NC-ND 4.0 International license .

\title{
Do Assisted Living Facilities That Offer a Dementia Care Program Differ from Those That Do Not? A Population-Level Cross-Sectional Study in Ontario, Canada
}

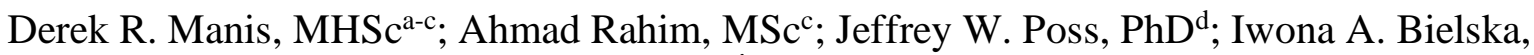
PhD ${ }^{\mathrm{a}, \mathrm{b}}$; Susan E. Bronskill, $\mathrm{PhD}^{\mathrm{c}, \mathrm{e}-\mathrm{g}}$; Jean-Éric Tarride, $\mathrm{PhD}^{\mathrm{a}, \mathrm{b}}$; Julia Abelson, $\mathrm{PhD}^{\mathrm{a}, \mathrm{b}}$; and Andrew P. Costa, $\mathrm{PhD}^{\mathrm{a}-\mathrm{c}, \mathrm{h}-\mathrm{j}}$

a. Centre for Health Economics and Policy Analysis, McMaster University, Hamilton, Ontario, Canada

b. Department of Health Research Methods, Evidence, and Impact, McMaster University, Hamilton, Ontario, Canada

c. ICES, Toronto, Ontario, Canada

d. School of Public Health and Health Systems, University of Waterloo, Waterloo, Ontario, Canada

e. Institute of Health Policy, Management \& Evaluation, University of Toronto, Toronto, Ontario, Canada

f. Women's College Research Institute, Toronto, Ontario, Canada

g. Sunnybrook Research Institute, Toronto, Ontario, Canada

h. Centre for Integrated Care, St. Joseph's Health System, Hamilton, Ontario, Canada

i. Schlegel Research Institute for Aging, Waterloo, Ontario, Canada

j. Department of Medicine, McMaster University, Hamilton, Ontario, Canada

Corresponding Author: Derek R. Manis, McMaster University, 1280 Main St W, CRL-201, Hamilton, ON L8S 4K1, Canada. (manisd@mcmaster.ca) Twitter: @DerekManis

\section{Running Title: "DEMENTIA CARE IN ASSISTED LIVING FACILITIES”}

Keywords: Assisted Living Facilities; Retirement Homes; Dementia Care; Canada

Funding: This research did not receive any funding from agencies in the public, commercial, or not-for-profit sectors.

Word Count: 1,811 (Max: 2,000)

Abstract: 287 (Max: 300)

References: 30 (Max: 30)

Exhibitions: 2 Tables (Max: 3) (2 Supplemental Tables in Appendix)

\section{BRIEF SUMMARY}

Question: Do licensed assisted living facilities that provide a dementia care program differ from those that do not in Ontario, Canada?

Findings: Assisted living facilities that provide a dementia care program house many older adults, have many suites, and offer at least five of the other 12 regulated care services.

Meaning: Assisted living facilities that provide a dementia care program are larger and provide an array of care services.

Disclosures: We have no perceived or actual conflicts, financial or otherwise, to disclose. 
medRxiv preprint doi: https://doi.org/10.1101/2021.02.06.21251214; this version posted February 9, 2021. The copyright holder for this preprint (which was not certified by peer review) is the author/funder, who has granted medRxiv a license to display the preprint in perpetuity. It is made available under a CC-BY-NC-ND 4.0 International license .

Acknowledgments: This study was supported by ICES, which is funded by an annual grant from the Ontario Ministry of Health and Long-Term Care (MOHLTC). The opinions, results and conclusions reported in this paper are those of the authors and are independent from the funding sources. No endorsement by ICES or the Ontario MOHLTC is intended or should be inferred. We extend our gratitude to Paul Pham, Adriane Castellino, and Chloe Ma at the Retirement Homes Regulatory Authority for sharing the registry of licensed assisted living facilities. We also extend our thanks to Nathan M. Stall for his comments on an earlier draft of this manuscript.

Author Contributions: DRM and APC conceptualized the study. AR created the dataset, and DRM conducted the statistical analyses. DRM wrote the manuscript, and all authors critically read and contributed to it.

Data Availability: The dataset from this study is held securely in coded form at ICES. While data sharing agreements prohibit ICES from making the data set publicly available, access may be granted to those who meet pre-specified criteria for confidential access, available at www.ices.on.ca/DAS. The full data set creation plan and underlying analytic code are available from the corresponding author upon request, understanding that the programs may rely upon coding templates or macros that are unique to ICES. 
medRxiv preprint doi: https://doi.org/10.1101/2021.02.06.21251214; this version posted February 9, 2021. The copyright holder for this preprint (which was not certified by peer review) is the author/funder, who has granted medRxiv a license to display the preprint in perpetuity.

It is made available under a CC-BY-NC-ND 4.0 International license .

DEMENTIA CARE IN ASSISTED LIVING FACILITIES

1 ABSTRACT

2 Objective: To identify the characteristics of licensed assisted living facilities that provide a

3 dementia care program compared to assisted living facilities that do not provide such a program.

4 Design, Setting, and Participants: Population-level cross-sectional study in Ontario, Canada on

5 all licensed assisted living facilities in $2018(n=738)$.

6 Methods: Data on facility-level characteristics (e.g., resident and suite capacities, etc.) and the

7 provision of other provincially regulated care services (e.g., pharmacist and medical services,

8 skin and wound care, etc.) attributed to licensed assisted living facilities were examined.

9 Multivariable Poisson regression with robust standard errors was used to model the characteristics of assisted living facilities associated with the provision of a dementia care program.

12 Results: There were $123(16.7 \%)$ assisted living facilities that provided a dementia care program. Nearly half of these facilities had a resident capacity exceeding 140 older adults (44.7\%) and more than 115 suites (46.3\%). All assisted living facilities that provided a dementia care program also provided nursing services, meals, assistance with bathing and hygiene, and administered medications. After adjusting for facility characteristics and other provincially

17 regulated care services, the prevalence of a dementia care program was nearly three times greater

18 in assisted living facilities that offered assistance with feeding than those that did not (Prevalence Ratio $[\mathrm{PR}]=2.91,95 \%$ Confidence Interval $[\mathrm{CI}] 1.98$ to 4.29$)$, and almost twice as great among assisted living facilities that provided medical services than those that did not $(\mathrm{PR}=1.78,95 \%$ CI 1.00 to 3.17$)$.

22 Conclusions: A dementia care program was more prevalent in assisted living facilities that 23 housed many older adults, had many suites, and provided at least five of the other 12 regulated 
medRxiv preprint doi: https://doi.org/10.1101/2021.02.06.21251214; this version posted February 9, 2021. The copyright holder for this preprint (which was not certified by peer review) is the author/funder, who has granted medRxiv a license to display the preprint in perpetuity. It is made available under a CC-BY-NC-ND 4.0 International license .

DEMENTIA CARE IN ASSISTED LIVING FACILITIES

24 care services. These findings deepen the understanding of specialized care for dementia in

25 assisted living facilities. 
medRxiv preprint doi: https://doi.org/10.1101/2021.02.06.21251214; this version posted February 9, 2021. The copyright holder for this preprint (which was not certified by peer review) is the author/funder, who has granted medRxiv a license to display the preprint in perpetuity.

It is made available under a CC-BY-NC-ND 4.0 International license.

DEMENTIA CARE IN ASSISTED LIVING FACILITIES

\section{INTRODUCTION}

Dementia affects more than half of all residents housed in assisted living facilities. ${ }^{1-3}$

Older adults living with dementia are more likely to experience injuries requiring acute care, be diagnosed with pneumonia, and encounter difficulties with eating. ${ }^{4,5}$ Care for dementia is expensive and a widely cited reason for older adults requiring placement in a nursing home. ${ }^{6-9}$ Specialized care for older adults living with dementia, such as a dementia care program, has demonstrated reductions in acute health service use and long-stay transitions to a nursing home..$^{8,10}$

Assisted living facilities are referred to as retirement homes in the province of Ontario, Canada. Similar to assisted living facilities in the United States that are regulated at the statelevel, ${ }^{11}$ retirement homes are regulated by an independent, not-for-profit regulator (i.e., Retirement Homes Regulatory Authority [RHRA]) in Ontario since 2011. ${ }^{12}$ The retirement home sector in Ontario has a resident capacity equivalent to that of its nursing home sector (i.e., more than 70,000 older adults), ${ }^{12}$ which demonstrates that it is a sizeable, important sector providing supportive care to older adults. Unlike nursing homes, residency in a retirement home is exclusively financed through private, out-of-pocket payments by residents and/or their family caregivers. $^{12-14}$

Much of the literature on dementia care in assisted living facilities addresses health service use among residents living with dementia, managing staff, and state-level regulations for dementia care. ${ }^{1,11,15-17}$ Studies explicitly investigating the characteristics of retirement homes or assisted living facilities that provide specialized care for dementia (i.e., a dementia care program), and how these characteristics compare to those that do not, are absent. The findings from such studies are important for identifying case mix and examining scope and breadth of 
medRxiv preprint doi: https://doi.org/10.1101/2021.02.06.21251214; this version posted February 9, 2021. The copyright holder for this preprint (which was not certified by peer review) is the author/funder, who has granted medRxiv a license to display the preprint in perpetuity.

It is made available under a CC-BY-NC-ND 4.0 International license .

care for older adults with complex care needs. A growing proportion of residents of assisted living facilities live with dementia, ${ }^{18}$ and improving the understanding of dementia care

51 programs in assisted living facilities contributes to informing the sector, community-based

52 dementia care, and national dementia care strategies. The objective of this study is to identify the

53 characteristics of licensed assisted living facilities that provide a dementia care program

54 compared to assisted living facilities that do not provide such a program in Ontario, Canada.

55 METHODS

56 Study Design and Setting

A population-level cross-sectional study was conducted at ICES in Ontario, Canada.

ICES is an independent, non-profit research institute funded by an annual grant from the Ontario

59 Ministry of Health and Long-Term Care. As a prescribed entity under Ontario's privacy

legislation, ICES is authorized to collect and use health care data for the purposes of health

61 system analysis, evaluation, and decision support. Secure access to these data is governed by

62 policies and procedures that are approved by the Information and Privacy Commissioner of

63 Ontario. The REporting of studies Conducted using Observational Routinely-collected health

64 Data (RECORD) statement guideline was followed (Appendix Table 2). ${ }^{19}$

65 Data

66

A list of all licensed assisted living facilities in Ontario in 2018 was obtained from the

67 public register of the RHRA and imported to ICES $(n=757)$. The postal code of each assisted

68 living facility was linked to Statistics Canada's Postal Code Conversion file, which is a

69 specialized macro for use with health system administrative datasets containing postal codes.

70 This macro is based on 2016 Census information, flags communities with a population less than

71 10,000 individuals as rural, and includes related data from Canada Post Corporation. ${ }^{20}$ Nineteen 
medRxiv preprint doi: https://doi.org/10.1101/2021.02.06.21251214; this version posted February 9, 2021. The copyright holder for this preprint (which was not certified by peer review) is the author/funder, who has granted medRxiv a license to display the preprint in perpetuity.

It is made available under a CC-BY-NC-ND 4.0 International license .

72 assisted living facilities $(n=19)$ were removed from the analysis because of missing facility-

73 level and postal code data.

74 Exposures

The exposures of interest are facility-level characteristics (i.e., urban location, resident capacity, total suites, chain status, residual home status, and co-location with a nursing home)

77 and the other 12 provincially regulated care services provided in an assisted living facility

78 (Appendix Table 1).

79 Outcome

The primary outcome is whether the assisted living facility provided a dementia care

81 program. Dementia care programs in assisted living facilities in Ontario are regulated to include

82 communication strategies, mental stimulation activities, health and wellness monitoring and

83 promotion, and identification of triggers for responsive behaviours. ${ }^{21}$ These programs must also

84 be supervised by a regulated health care professional (e.g., registered nurse, physician, etc.), 85 align with current evidence and best practices for dementia care, and be evaluated annually. ${ }^{21}$

\section{Statistical Analysis}

Counts, percentages, and standardized differences were calculated to describe the facilitylevel and care service characteristics of assisted living facilities that provided, and did not provide, a dementia care program. ${ }^{22}$ Multivariable Poisson regression with robust standard errors was used to model unadjusted and adjusted estimates with $95 \%$ confidence intervals to identify the characteristics of assisted living facilities associated with the provision of a dementia care program. $^{23,24}$ Tests were two-tailed, and the level of statistical significance was set at $\alpha=0.05$.

The deviance goodness-of-fit test was calculated to assess whether the Poisson regression model was appropriate. Variance inflation factors were calculated to assess for multicollinearity. ${ }^{25}$ Data 
medRxiv preprint doi: https://doi.org/10.1101/2021.02.06.21251214; this version posted February 9, 2021. The copyright holder for this preprint (which was not certified by peer review) is the author/funder, who has granted medRxiv a license to display the preprint in perpetuity.

It is made available under a CC-BY-NC-ND 4.0 International license .

set processing was conducted in SAS Enterprise 9.4 (Cary, NC, USA) and statistical analyses were conducted in Stata MP 16.1 (College Station, TX, USA).

\section{RESULTS}

There were 738 licensed assisted living facilities in Ontario in $2018(n=738)$. Of these, 123 provided a dementia care program ( $16.7 \%$ versus $83.3 \%$ no dementia care program), and almost all were located in an urban area $(92.7 \%$ versus $82.6 \%$ no dementia care program) (Table 1). Nearly half of these assisted living facilities had a resident capacity of 140 or more (44.7\% versus $21.6 \%$ no dementia care program) and had more than 115 suites ( $46.3 \%$ versus $20.8 \%$ no dementia care program). All assisted living facilities that provided a dementia care program also provided nursing services, meals, assistance with bathing and hygiene, and administered medications $(n=123)$. Many of the standardized differences between assisted living facilities that provided a dementia care program and those that did not exceeded $10 \%$, which indicated that assisted living facilities that provided a dementia care program were systematically different from those that did not. ${ }^{22}$

Assistance with bathing and hygiene, provision of meals, administration of medication, and nursing services were removed from the adjusted model because of collinearity, and there was no evidence of multicollinearity in the adjusted model (i.e., variance inflation factors equal to or greater than a value of 10). ${ }^{25}$ The deviance goodness-of-fit statistic was not statistically significant. After adjusting for facility characteristics and regulated care services, the prevalence of a dementia care program was almost three times greater in assisted living facilities with 115 or more suites (Prevalence Ratio $[\mathrm{PR}]=2.78,95 \%$ Confidence Interval [CI] 1.09 to 7.07 ) compared to assisted living facilities with 41 or fewer suites (Table 2). The prevalence of a dementia care program was nearly three times greater in assisted living facilities that provided assistance with 
medRxiv preprint doi: https://doi.org/10.1101/2021.02.06.21251214; this version posted February 9, 2021. The copyright holder for this preprint (which was not certified by peer review) is the author/funder, who has granted medRxiv a license to display the preprint in perpetuity.

It is made available under a CC-BY-NC-ND 4.0 International license .

118 feeding (PR $=2.91,95 \%$ CI 1.98 to 4.29$)$, and the prevalence of a dementia care program was

119 almost twice as great in assisted living facilities that provided medical services $(\mathrm{PR}=1.78,95 \%$

120 CI 1.00 to 3.17), compared to assisted living facilities that did not provide these care services.

\section{DISCUSSION}

Assisted living facilities that provided a dementia care program were systematically

123 different from those that did not provide such a program. Specifically, assisted living facilities in

124 Ontario that provided a dementia program had large resident capacities, many suites, and

125 provided, at a minimum, nursing services, meals, assistance with bathing and hygiene, and

126 administered medications. The prevalence of a dementia care program in an assisted living

127 facility was greater in assisted living facilities where assistance with feeding and medical

128 services were also provided.

More than $90 \%$ of assisted living facilities that provided a dementia care program were

located in urban communities. Consistent with existing literature, this finding raises important

equity considerations for older adults living with dementia in assisted living facilities located in

132 rural and remote regions. ${ }^{26}$ Rural assisted living facilities house fewer older adults and are more

133 likely to have deficiencies in care provision than urban ones, including challenges with retaining

134 appropriate care staff and resources to meet the needs of residents. ${ }^{27}$ The use of

135 videoconferencing and other information technology resources to provide dementia care should

136 be considered to improve access to care for individuals living with dementia in rural and remote

137 areas. $^{28}$

Most assisted living facilities that provided a dementia care program had capacity for 
medRxiv preprint doi: https://doi.org/10.1101/2021.02.06.21251214; this version posted February 9, 2021. The copyright holder for this preprint (which was not certified by peer review) is the author/funder, who has granted medRxiv a license to display the preprint in perpetuity.

It is made available under a CC-BY-NC-ND 4.0 International license .

characteristic of institutionalized congregate care,${ }^{29}$ and the presence and statistically significant association of many suites in assisted living facilities that provide a dementia care program aligns with the literature. In addition, this may indicate that many assisted living facilities that provide a dementia care program are large complexes, likely attributed to chains.

Given the challenges that older adults living with dementia face with respect to eating, ${ }^{5}$ it is expected that assistance with feeding would be a prevalent care service offered alongside a dementia care program in an assisted living facility. Moreover, the complex and intersecting care needs of older adults living with dementia, which includes polypharmacy, ${ }^{30}$ underscores the need for a physician to monitor and evaluate the care plan. As such, the prevalence of medical services in assisted living facilities that offer a dementia care program is also expected.

As the assisted living sector is privately financed in Ontario, this study makes an important contribution to the literature to define the sector by modeling facility-level characteristics associated with the provision of a dementia care program. The findings are relevant to clinicians and policymakers actively considering dementia care options in communities to support older adults living with dementia and their caregivers. Family caregivers and consumers of assisted living services will also be interested in these findings to inform their decisions for care.

A limitation to this study is that the fees older adults residing in assisted living facilities pay each month and per care service could not be included in the adjusted model. This is due, in part, to the inability to capture this information in existing administrative health system data. Moreover, these data are not publicly available on the websites of assisted living facilities, through their member associations, or available to the RHRA through regulatory reporting requirements. Another limitation is that this study is descriptive; as such, no causal or temporal 
medRxiv preprint doi: https://doi.org/10.1101/2021.02.06.21251214; this version posted February 9, 2021. The copyright holder for this preprint (which was not certified by peer review) is the author/funder, who has granted medRxiv a license to display the preprint in perpetuity.

It is made available under a CC-BY-NC-ND 4.0 International license .

164 claims can be made about the associations between the facility-level characteristics of assisted

165 living facilities and the provision of a dementia care program. As with all secondary analyses of

166 data, the data used in this study are susceptible to misclassification bias.

\section{CONCLUSION}

This study identified and compared facility-level characteristics of licensed assisted

169 living facilities that provided a dementia care program to those that did not in Ontario, Canada in

170 2018. Assisted living facilities that offered a dementia care program housed more older adults

171 and provided more care services. Future research might consider investigating the underlying

172 differences in populations between residents of these facilities and their health outcomes

173 attributed to care services provided in assisted living facilities. 
medRxiv preprint doi: https://doi.org/10.1101/2021.02.06.21251214; this version posted February 9, 2021. The copyright holder for this preprint (which was not certified by peer review) is the author/funder, who has granted medRxiv a license to display the preprint in perpetuity. It is made available under a CC-BY-NC-ND 4.0 International license .

\section{REFERENCES}

1. Thomas KS, Zhang W, Cornell PY, Smith L, Kaskie B, Carder PC. State Variability in the Prevalence and Healthcare Utilization of Assisted Living Residents with Dementia. J Am Geriatr Soc. 2020;68(7):1504-1511. doi:10.1111/jgs.16410

2. Thomas KS, Dosa D, Gozalo PL, et al. A Methodology to Identify a Cohort of Medicare Beneficiaries Residing in Large Assisted Living Facilities Using Administrative Data. Med Care. 2018;56(2):e10-e15. doi:10.1097/MLR.0000000000000659

3. Zimmerman S, Sloane PD, Reed D. Dementia prevalence and care in assisted living. Health Aff (Millwood). 2014;33(4):658-666. doi:10.1377/hlthaff.2013.1255

4. Rosa TD, Possin KL, Bernstein A, et al. Variations in Costs of a Collaborative Care Model for Dementia. J Am Geriatr Soc. 2019;67(12):2628-2633. doi:10.1111/jgs.16076

5. Mitchell SL, Teno JM, Kiely DK, et al. The Clinical Course of Advanced Dementia. N Engl J Med. 2009;361(16):1529-1538. doi:10.1056/NEJMoa0902234

6. Ng R, Lane N, Tanuseputro P, et al. Increasing Complexity of New Nursing Home Residents in Ontario, Canada: A Serial Cross-Sectional Study. Journal of the American Geriatrics Society. 2020;68(6):1293-1300. doi:10.1111/jgs.16394

7. Mondor L, Maxwell CJ, Hogan DB, et al. The Incremental Health Care Costs of Frailty Among Home Care Recipients With and Without Dementia in Ontario, Canada: A Cohort Study. Medical Care. 2019;57(7):512-520. doi:10.1097/MLR.0000000000001139

8. Jennings LA, Laffan AM, Schlissel AC, et al. Health Care Utilization and Cost Outcomes of a Comprehensive Dementia Care Program for Medicare Beneficiaries. JAMA Intern Med. 2019;179(2):161-166. doi:10.1001/jamainternmed.2018.5579

9. Morton-Chang F, Williams AP, Berta W, Laporte A. Towards a Community-Based Dementia Care Strategy: How do We Get There from Here? World Health \& Population. 2019;18(1):6-39. doi:10.12927/whp.2019.26062

10. Jennings LA, Hollands S, Keeler E, Wenger NS, Reuben DB. The Effects of Dementia Care Co-Management on Acute Care, Hospice, and Long-Term Care Utilization. J Am Geriatr Soc. 2020;(7503062, h6v). doi:10.1111/jgs.16667

11. Nattinger MC, Kaskie B. Determinants of the Rigor of State Protection Policies for Persons With Dementia in Assisted Living. J Aging Soc Policy. 2017;29(2):123-142. doi:10.1080/08959420.2016.1236324

12. Roblin B, Deber R, Kuluski K, Silver MP. Ontario's Retirement Homes and Long-Term Care Homes: A Comparison of Care Services and Funding Regimes. Can J Aging. 2019;38(2):155-167. doi:10.1017/S0714980818000569 
medRxiv preprint doi: https://doi.org/10.1101/2021.02.06.21251214; this version posted February 9, 2021. The copyright holder for this preprint (which was not certified by peer review) is the author/funder, who has granted medRxiv a license to display the preprint in perpetuity. It is made available under a CC-BY-NC-ND 4.0 International license .

13. Silver BC, Grabowski DC, Gozalo PL, Dosa D, Thomas KS. Increasing Prevalence of Assisted Living as a Substitute for Private-Pay Long-Term Nursing Care. Health Serv Res. 2018;53(6):4906-4920. doi:10.1111/1475-6773.13021

14. Grabowski DC, Stevenson DG, Cornell PY. Assisted living expansion and the market for nursing home care. Health Services Research. 2012;47(6):2296-2315. doi:10.1111/j.14756773.2012.01425.x

15. Simmons SF, Coelho CS, Sandler A, Schnelle JF. A System for Managing Staff and Quality of Dementia Care in Assisted Living Facilities. J Am Geriatr Soc. 2018;66(8):1632-1637. doi:10.1111/jgs.15463

16. Simmons SF, Coelho CS, Sandler A, Shah AS, Schnelle JF. Managing Person-Centered Dementia Care in an Assisted Living Facility: Staffing and Time Considerations. Gerontologist. 2018;58(4):e251-e259. doi:10.1093/geront/gnx089

17. Carder PC. State Regulatory Approaches for Dementia Care in Residential Care and Assisted Living. Gerontologist. 2017;57(4):776-786. doi:10.1093/geront/gnw197

18. Cornell PY, Zhang W, Smith L, Fashaw S, Thomas KS. Developments in the Market for Assisted Living: Residential Care Availability in 2017. J Am Med Dir Assoc. 2020;21(11):1718-1723. doi:10.1016/j.jamda.2020.08.011

19. Benchimol EI, Smeeth L, Guttmann A, et al. The REporting of studies Conducted using Observational Routinely-collected health Data (RECORD) Statement. PLOS Medicine. 2015;12(10):e1001885. doi:10.1371/journal.pmed.1001885

20. Government of Canada SC. Postal Code OM Conversion File Plus (PCCF+). Published March 6, 2017. Accessed November 24, 2020. https://www150.statcan.gc.ca/n1/en/catalogue/82F0086X

21. Government of Ontario. O. Reg. 166/11: GENERAL.; 2014. Accessed June 17, 2020. https://www.ontario.ca/laws/regulation/110166\#BK54

22. Austin PC. Using the Standardized Difference to Compare the Prevalence of a Binary Variable Between Two Groups in Observational Research. Communications in Statistics Simulation and Computation. 2009;38(6):1228-1234. doi:10.1080/03610910902859574

23. Barros AJ, Hirakata VN. Alternatives for logistic regression in cross-sectional studies: an empirical comparison of models that directly estimate the prevalence ratio. BMC Med Res Methodol. 2003;3(1):1-13. doi:10.1186/1471-2288-3-21

24. Tamhane AR, Westfall AO, Burkholder GA, Cutter GR. Prevalence Odds Ratio versus Prevalence Ratio: Choice Comes with Consequences. Stat Med. 2016;35(30):5730-5735. doi:10.1002/sim.7059

25. Kleinbaum DG, Kupper LL, Nizam A, Rosenberg ES. Applied Regression Analysis and Other Multivariable Methods. 5th ed. Cengage Learning; 2014. 
medRxiv preprint doi: https://doi.org/10.1101/2021.02.06.21251214; this version posted February 9, 2021. The copyright holder for this preprint

(which was not certified by peer review) is the author/funder, who has granted medRxiv a license to display the preprint in perpetuity.

It is made available under a CC-BY-NC-ND 4.0 International license .

DEMENTIA CARE IN ASSISTED LIVING FACILITIES

26. Giebel C. "Current dementia care: what are the difficulties and how can we advance care globally?”. BMC Health Serv Res. 2020;20(1):414. doi:10.1186/s12913-020-05307-1

27. June JW, Meng H, Dobbs D, Hyer K. Using Deficiency Data to Measure Quality in Assisted Living Communities: A Florida Statewide Study. J Aging Soc Policy. 2020;32(2):125-140. doi:10.1080/08959420.2018.1563471

28. Wallack EM, Harris C, Ploughman M, Butler R. Telegerontology as a Novel Approach to Address Health and Safety by Supporting Community-Based Rural Dementia Care Triads: Randomized Controlled Trial Protocol. JMIR Res Protoc. 2018;7(2):e56. doi:10.2196/resprot.8744

29. Calkins MP. From Research to Application: Supportive and Therapeutic Environments for People Living With Dementia. Gerontologist. 2018;58(suppl_1):S114-S128. doi:10.1093/geront/gnx146

30. Mueller C, Molokhia M, Perera G, et al. Polypharmacy in people with dementia: Associations with adverse health outcomes. Experimental Gerontology. 2018;106:240-245. doi:10.1016/j.exger.2018.02.011 
medRxiv preprint doi: https://doi.org/10.1101/2021.02.06.21251214; this version posted February 9, 2021. The copyright holder for this preprint (which was not certified by peer review) is the author/funder, who has granted medRxiv a license to display the preprint in perpetuity. It is made available under a CC-BY-NC-ND 4.0 International license .

DEMENTIA CARE IN ASSISTED LIVING FACILITIES

Table 1. Descriptive Characteristics of Licensed Assisted Living Facilities in $2018(n=738)$

\begin{tabular}{|c|c|c|c|}
\hline & \multicolumn{2}{|c|}{ Dementia Care Program } & \multirow{2}{*}{$\begin{array}{l}\text { Standardized } \\
\text { Difference }\end{array}$} \\
\hline & Yes & No & \\
\hline$n(\%)$ & $123(16.7)$ & $615(83.3)$ & \\
\hline \multicolumn{4}{|l|}{ Facility Characteristics, $n(\%)$} \\
\hline Urban Location & $114(92.7)$ & $508(82.6)$ & 0.309 \\
\hline Facility Capacity & & & 0.583 \\
\hline $6-49$ & $24(19.5)$ & $155(25.2)$ & \\
\hline $50-86$ & $14(11.4)$ & $171(27.8)$ & \\
\hline $87-139$ & $30(24.4)$ & $156(25.4)$ & \\
\hline $140+$ & $55(44.7)$ & $133(21.6)$ & \\
\hline Total Suites & & & 0.615 \\
\hline $6-41$ & $20(16.3)$ & $163(26.5)$ & \\
\hline $42-70$ & $16(13.0)$ & $168(27.3)$ & \\
\hline $71-114$ & $30(24.4)$ & $156(25.4)$ & \\
\hline $115+$ & $57(46.3)$ & $128(20.8)$ & \\
\hline Chain Status & $74(60.2)$ & $281(45.7)$ & 0.293 \\
\hline Residential Home & $8(6.5)$ & $71(11.5)$ & 0.176 \\
\hline Co-Located with Nursing Home & $19(15.4)$ & $112(18.2)$ & 0.073 \\
\hline \multicolumn{4}{|l|}{ Care Services, $n(\%)$} \\
\hline Assistance with Bathing & $123(100.0)$ & $581(94.5)$ & 0.342 \\
\hline Assistance with Hygiene & $123(100.0)$ & $531(86.3)$ & 0.562 \\
\hline Assistance with Ambulation & $\begin{array}{l}117 \text { to } 123 \text { (95.1 to } \\
100.0)^{*}\end{array}$ & $517(84.1)$ & 0.480 \\
\hline Assistance with Feeding & $89(72.4)$ & $185(30.1)$ & 0.933 \\
\hline Assistance with Dressing & $\begin{array}{l}117 \text { to } 123 \text { (95.1 to } \\
100.0)^{*}\end{array}$ & $532(86.5)$ & 0.507 \\
\hline Continence Care & $\begin{array}{l}117 \text { to } 123 \text { (95.1 to } \\
100.0)^{*}\end{array}$ & $457(74.3)$ & 0.788 \\
\hline Skin and Wound Care & $47(38.2)$ & $113(18.4)$ & 0.451 \\
\hline Provision of Meals & $123(100.0)$ & $\begin{array}{l}609 \text { to } 615 \text { (99.0 to } \\
100.0)\end{array}$ & 0.057 \\
\hline Administration of Medications & $123(100.0)$ & $\begin{array}{l}609 \text { to } 615 \text { (99.0 to } \\
100.0)^{*}\end{array}$ & 0.114 \\
\hline Pharmacist Services & $\begin{array}{l}117 \text { to } 123 \text { (95.1 to } \\
100.0)^{*}\end{array}$ & $535(87.0)$ & 0.287 \\
\hline Nursing Services & $123(100.0)$ & $574(93.3)$ & 0.377 \\
\hline Medical Services & $107(87.0)$ & $401(65.2)$ & 0.528 \\
\hline
\end{tabular}

\footnotetext{
* Small cell sizes (i.e., where six or fewer assisted living facilities have, or do not have, a characteristic) are suppressed due to privacy restrictions at ICES
} 
medRxiv preprint doi: https://doi.org/10.1101/2021.02.06.21251214; this version posted February 9, 2021. The copyright holder for this preprint (which was not certified by peer review) is the author/funder, who has granted medRxiv a license to display the preprint in perpetuity.

It is made available under a CC-BY-NC-ND 4.0 International license .

DEMENTIA CARE IN ASSISTED LIVING FACILITIES

Table 2. Associations with the Provision of a Dementia Care Program in Licensed Assisted Living Facilities

\begin{tabular}{|c|c|c|}
\hline & Unadjusted PR (95\% CI) & Adjusted PR (95\% CI) $\dagger$ \\
\hline \multicolumn{3}{|l|}{ Facility Characteristics } \\
\hline Urban & $2.26(1.23 \text { to } 4.52)^{* *}$ & $1.15(0.61$ to 2.17$)$ \\
\hline \multicolumn{3}{|l|}{ Facility Capacity } \\
\hline $6-49$ & 1.00 (Reference) & 1.00 (Reference) \\
\hline $50-86$ & $0.56(0.30$ to 1.06$)$ & $0.34(0.18 \text { to } 0.66)^{* *}$ \\
\hline $87-139$ & $1.20(0.73$ to 1.98$)$ & $0.43(0.20$ to 0.93$) *$ \\
\hline $140+$ & $2.18(1.41 \text { to } 3.37)^{* * *}$ & $0.59(0.25$ to 1.42$)$ \\
\hline \multicolumn{3}{|l|}{ Total Suites } \\
\hline $6-41$ & 1.00 (Reference) & 1.00 (Reference) \\
\hline $42-70$ & $0.80(0.43$ to 1.49$)$ & $1.40(0.73$ to 2.70$)$ \\
\hline $71-114$ & $1.48(0.87$ to 2.50$)$ & $2.28(1.02$ to 5.11$) *$ \\
\hline $115+$ & $2.82(1.77 \text { to } 4.50)^{* * *}$ & $2.78(1.09$ to 7.07$) *$ \\
\hline Chain Status & $1.63(1.17 \text { to } 2.27)^{* *}$ & $1.21(0.88$ to 1.67$)$ \\
\hline Residential Home & $0.58(0.29$ to 1.14$)$ & $0.75(0.35$ to 1.61$)$ \\
\hline $\begin{array}{l}\text { Co-Located with a Nursing Home } \\
\text { Care Services }\end{array}$ & $0.85(0.54$ to 1.33$)$ & $1.21(0.78$ to 1.87$)$ \\
\hline Assistance with Ambulation & $6.34(2.05 \text { to } 19.57)^{* *}$ & $0.96(0.34$ to 2.75$)$ \\
\hline Assistance with Feeding & $4.43(3.07 \text { to } 6.39)^{* * *}$ & $2.91(1.98 \text { to } 4.29)^{* * *}$ \\
\hline Assistance with Dressing & $15.67(2.22 \text { to } 110.82)^{* *}$ & $2.24(0.26$ to 18.96$)$ \\
\hline Continence Care & $33.50(4.71 \text { to } 238.20)^{* * *}$ & $13.51(1.64 \text { to } 111.67)^{*}$ \\
\hline Skin and Wound Care & $2.23(1.62 \text { to } 3.07)^{* * *}$ & $1.18(0.85$ to 1.63$)$ \\
\hline Pharmacist Services & $2.57(1.17 \text { to } 5.66)^{*}$ & $0.91(0.38$ to 2.21$)$ \\
\hline Medical Services & $3.03(1.83 \text { to } 5.00)^{* * *}$ & $1.78(1.00$ to 3.17$) *$ \\
\hline
\end{tabular}

$\mathrm{PR}=$ Prevalence Ratio; $\mathrm{CI}=$ Confidence Interval

†Adjusted for all variables in the table

${ }^{*} p<0.05 ;{ }^{* *} p<0.01 ;{ }^{* * *} p<0.001$ 


\section{APPENDIX}

Appendix Table 1. Detailed Descriptions of Exposures

\begin{tabular}{|c|c|}
\hline Variable & Description \\
\hline Urban & $\begin{array}{l}\text { Based on the PCCF flag, which is a specialized macro for use with } \\
\text { health system administrative datasets containing postal codes. This } \\
\text { macro is based on } 2016 \text { Census information, flags communities with } \\
\text { a population less than 10,000 individuals as rural, and it includes } \\
\text { related data from Canada Post Corporation. }\end{array}$ \\
\hline Facility Capacity & $\begin{array}{l}\text { Resident capacity of the assisted living facilities. This variable was } \\
\text { transformed into quartiles for ease of interpretation. }\end{array}$ \\
\hline Total Suites & $\begin{array}{l}\text { Number of suites in the assisted living facility. This variable was } \\
\text { transformed into quartiles for ease of interpretation. }\end{array}$ \\
\hline Chain Status & $\begin{array}{l}\text { Binary variable specifying whether the assisted living facility is part } \\
\text { of a chain. Chains are defined as two or more assisted living } \\
\text { facilities owned and operated by the same entity. }\end{array}$ \\
\hline Residential Home & $\begin{array}{l}\text { Binary variable specifying whether the assisted living facility is a } \\
\text { residential home. Residential homes are not facilities and are } \\
\text { located in residential areas. }\end{array}$ \\
\hline $\begin{array}{l}\text { Co-Located with a } \\
\text { Nursing Home }\end{array}$ & $\begin{array}{l}\text { Binary variable specifying whether the assisted living facility is co- } \\
\text { located with a nursing home in the same building or land site. }\end{array}$ \\
\hline $\begin{array}{l}\text { Assistance with } \\
\text { Bathing }\end{array}$ & $\begin{array}{l}\text { Binary variable specifying whether the assisted living facility } \\
\text { provides bathing respecting privacy and preferences. }\end{array}$ \\
\hline $\begin{array}{l}\text { Assistance with } \\
\text { Hygiene }\end{array}$ & $\begin{array}{l}\text { Binary variable specifying whether the assisted living facility } \\
\text { provides grooming, oral care, foot care, and care for fingernails. }\end{array}$ \\
\hline $\begin{array}{l}\text { Assistance with } \\
\text { Ambulation }\end{array}$ & $\begin{array}{l}\text { Binary variable specifying whether the assisted living facility } \\
\text { provides assistance with mobility devices and transferring and } \\
\text { positioning techniques. }\end{array}$ \\
\hline $\begin{array}{l}\text { Assistance with } \\
\text { Feeding }\end{array}$ & $\begin{array}{l}\text { Binary variable specifying whether the assisted living facility } \\
\text { provides assistance to residents to eat and drink safely, including } \\
\text { assistance inserting and removing dentures. }\end{array}$ \\
\hline $\begin{array}{l}\text { Assistance with } \\
\text { Dressing }\end{array}$ & $\begin{array}{l}\text { Binary variable specifying whether the assisted living facility } \\
\text { provides assistance with dressing, consistent with time of day and } \\
\text { weather conditions. }\end{array}$ \\
\hline Continence Care & $\begin{array}{l}\text { Binary variable specifying whether the assisted living facility } \\
\text { provides continence products and measures to prevent constipation. }\end{array}$ \\
\hline Skin and Wound Care & $\begin{array}{l}\text { Binary variable specifying whether the assisted living facility } \\
\text { provides interventions and routine care to maintain the integrity of } \\
\text { the resident's skin, prevent wounds and infections, and other } \\
\text { preventive measures (e.g., physiotherapy, etc.). }\end{array}$ \\
\hline Provision of Meals & $\begin{array}{l}\text { Binary variable specifying whether the assisted living facility } \\
\text { provides meals supporting good nutrition standards, food service } \\
\text { workers, and individualized meals, if required. }\end{array}$ \\
\hline $\begin{array}{l}\text { Administration of } \\
\text { Medications }\end{array}$ & $\begin{array}{l}\text { Binary variable specifying whether the assisted living facility stores } \\
\text { medications and has regulated health professionals providing } \\
\text { medication to residents consistent with their needs and care plans. }\end{array}$ \\
\hline
\end{tabular}


medRxiv preprint doi: https://doi.org/10.1101/2021.02.06.21251214; this version posted February 9, 2021. The copyright holder for this preprint (which was not certified by peer review) is the author/funder, who has granted medRxiv a license to display the preprint in perpetuity. It is made available under a CC-BY-NC-ND 4.0 International license .

DEMENTIA CARE IN ASSISTED LIVING FACILITIES

Appendix Table 1. Detailed Descriptions of Exposures

\begin{tabular}{ll}
\hline Variable & Description \\
\hline Pharmacist Services & $\begin{array}{l}\text { Binary variable specifying whether the assisted living facility } \\
\text { provides services from a pharmacist regulated by the Ontario } \\
\text { College of Pharmacists. }\end{array}$ \\
\hline Nursing Services & $\begin{array}{l}\text { Binary variable specifying whether the assisted living facility } \\
\text { provides services from a nurse regulated by the Ontario College of } \\
\text { Nurses. }\end{array}$ \\
\hline Medical Services & $\begin{array}{l}\text { Binary variable specifying whether the assisted living facility } \\
\text { provides services from a physician regulated by the Ontario College } \\
\text { of Physicians and Surgeons. }\end{array}$ \\
\hline $\begin{array}{l}\text { Detailed descriptions of the care services are found in O. Reg. 166/11: GENERAL under Retirement Homes Act, } \\
\text { 2010, S.O. 2010, c. 11. Available at: https://www.ontario.ca/laws/regulation/110166\#BK47 }\end{array}$
\end{tabular}


Appendix Table 2. RECORD Checklist

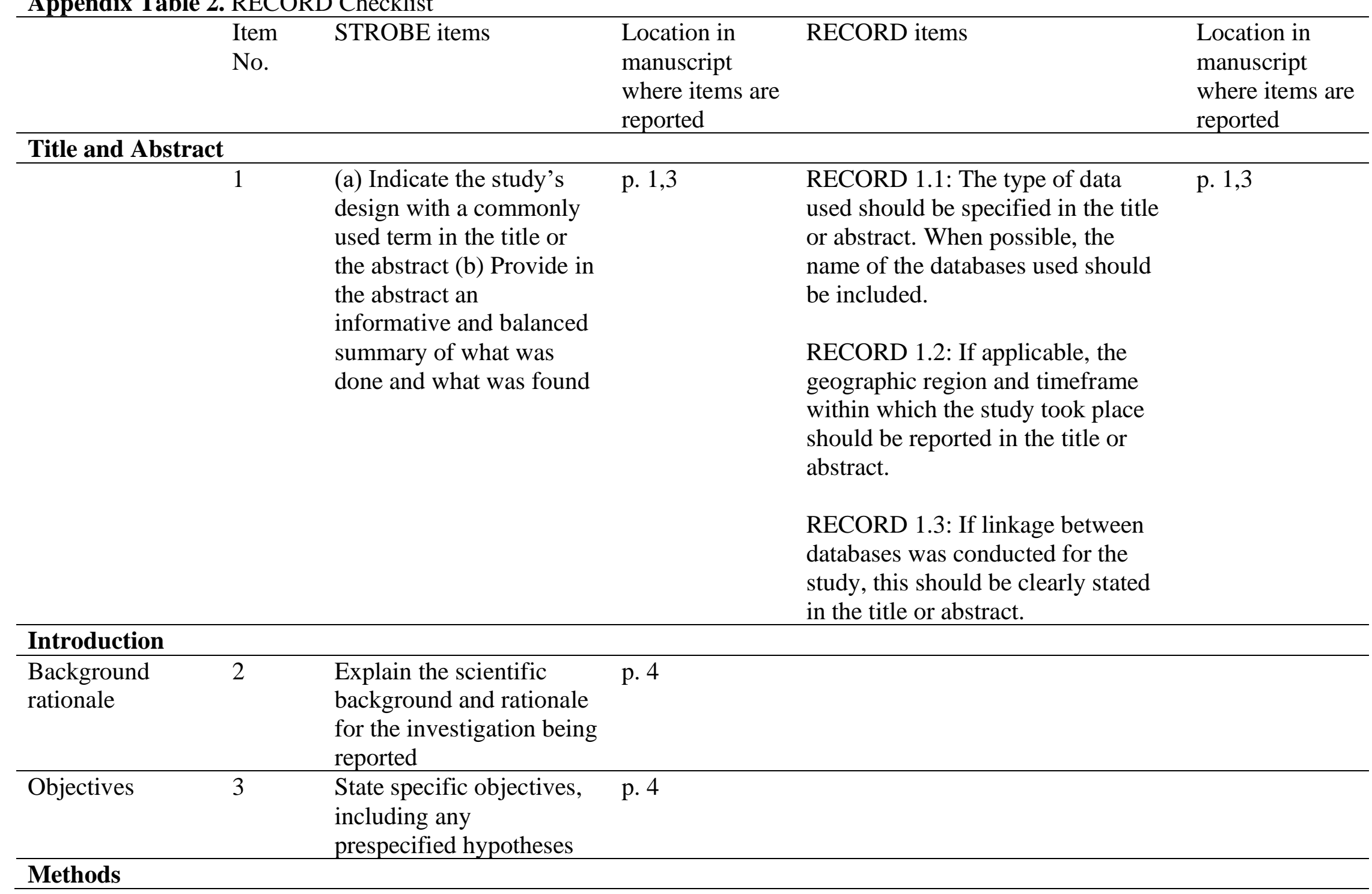


Appendix Table 2. RECORD Checklist

\begin{tabular}{|c|c|c|c|c|c|}
\hline & $\begin{array}{l}\text { Item } \\
\text { No. }\end{array}$ & STROBE items & $\begin{array}{l}\text { Location in } \\
\text { manuscript } \\
\text { where items are } \\
\text { reported }\end{array}$ & RECORD items & $\begin{array}{l}\text { Location in } \\
\text { manuscript } \\
\text { where items are } \\
\text { reported }\end{array}$ \\
\hline Study Design & 4 & $\begin{array}{l}\text { Present key elements of } \\
\text { study design early in the } \\
\text { paper }\end{array}$ & p. 5 & & \\
\hline Setting & 5 & $\begin{array}{l}\text { Describe the setting, } \\
\text { locations, and relevant } \\
\text { dates, including periods } \\
\text { of recruitment, exposure, } \\
\text { follow-up, and data } \\
\text { collection }\end{array}$ & p. 5 & & \\
\hline Participants & 6 & $\begin{array}{l}\text { (a) Cohort study - Give } \\
\text { the eligibility criteria, and } \\
\text { the sources and methods } \\
\text { of selection of } \\
\text { participants. Describe } \\
\text { methods of follow-up } \\
\text { Case-control study - Give } \\
\text { the eligibility criteria, and } \\
\text { the sources and methods } \\
\text { of case ascertainment and } \\
\text { control selection. Give the } \\
\text { rationale for the choice of } \\
\text { cases and controls } \\
\text { Cross-sectional study - } \\
\text { Give the eligibility } \\
\text { criteria, and the sources } \\
\text { and methods of selection } \\
\text { of participants }\end{array}$ & p. 5 & $\begin{array}{l}\text { RECORD 6.1: The methods of } \\
\text { study population selection (such as } \\
\text { codes or algorithms used to identify } \\
\text { subjects) should be listed in detail. } \\
\text { If this is not possible, an } \\
\text { explanation should be provided. } \\
\text { RECORD 6.2: Any validation } \\
\text { studies of the codes or algorithms } \\
\text { used to select the population should } \\
\text { be referenced. If validation was } \\
\text { conducted for this study and not } \\
\text { published elsewhere, detailed } \\
\text { methods and results should be } \\
\text { provided. } \\
\text { RECORD 6.3: If the study involved } \\
\text { linkage of databases, consider use of } \\
\text { a flow diagram or other graphical }\end{array}$ & p. 5 \\
\hline
\end{tabular}




\begin{tabular}{|c|c|c|c|c|c|}
\hline & $\begin{array}{l}\text { Item } \\
\text { No. }\end{array}$ & STROBE items & $\begin{array}{l}\text { Location in } \\
\text { manuscript } \\
\text { where items are } \\
\text { reported }\end{array}$ & RECORD items & $\begin{array}{l}\text { Location in } \\
\text { manuscript } \\
\text { where items are } \\
\text { reported }\end{array}$ \\
\hline & & $\begin{array}{l}\text { (b) Cohort study - For } \\
\text { matched studies, give } \\
\text { matching criteria and } \\
\text { number of exposed and } \\
\text { unexposed } \\
\text { Case-control study - For } \\
\text { matched studies, give } \\
\text { matching criteria and the } \\
\text { number of controls per } \\
\text { case }\end{array}$ & & $\begin{array}{l}\text { display to demonstrate the data } \\
\text { linkage process, including the } \\
\text { number of individuals with linked } \\
\text { data at each stage. }\end{array}$ & \\
\hline Variables & 7 & $\begin{array}{l}\text { Clearly define all } \\
\text { outcomes, exposures, } \\
\text { predictors, potential } \\
\text { confounders, and effect } \\
\text { modifiers. Give } \\
\text { diagnostic criteria, if } \\
\text { applicable. }\end{array}$ & p. $5,6,16,17$ & $\begin{array}{l}\text { RECORD 7.1: A complete list of } \\
\text { codes and algorithms used to } \\
\text { classify exposures, outcomes, } \\
\text { confounders, and effect modifiers } \\
\text { should be provided. If these cannot } \\
\text { be reported, an explanation should } \\
\text { be provided. }\end{array}$ & p. $5,6,16,17$ \\
\hline $\begin{array}{l}\text { Data sources/ } \\
\text { measurement }\end{array}$ & 8 & $\begin{array}{l}\text { For each variable of } \\
\text { interest, give sources of } \\
\text { data and details of } \\
\text { methods of assessment } \\
\text { (measurement). } \\
\text { Describe comparability of } \\
\text { assessment methods if } \\
\text { there is more than one } \\
\text { group }\end{array}$ & p. $5,6,16,17$ & & \\
\hline
\end{tabular}




\begin{tabular}{|c|c|c|c|c|}
\hline & $\begin{array}{l}\text { Item } \\
\text { No. }\end{array}$ & STROBE items & $\begin{array}{l}\text { Location in } \\
\text { manuscript } \\
\text { where items are } \\
\text { reported }\end{array}$ & $\begin{array}{l}\text { Location in } \\
\text { manuscript } \\
\text { where items are } \\
\text { reported }\end{array}$ \\
\hline Bias & 9 & $\begin{array}{l}\text { Describe any efforts to } \\
\text { address potential sources } \\
\text { of bias }\end{array}$ & p. 5,6 & \\
\hline Study size & 10 & $\begin{array}{l}\text { Explain how the study } \\
\text { size was arrived at }\end{array}$ & p. 6 & \\
\hline $\begin{array}{l}\text { Quantitative } \\
\text { variables }\end{array}$ & 11 & $\begin{array}{l}\text { Explain how quantitative } \\
\text { variables were handled in } \\
\text { the analyses. If } \\
\text { applicable, describe } \\
\text { which groupings were } \\
\text { chosen, and why }\end{array}$ & p. 6 & \\
\hline $\begin{array}{l}\text { Statistical } \\
\text { methods }\end{array}$ & 12 & $\begin{array}{l}\text { (a) Describe all statistical } \\
\text { methods, including those } \\
\text { used to control for } \\
\text { confounding } \\
\text { (b) Describe any methods } \\
\text { used to examine } \\
\text { subgroups and } \\
\text { interactions } \\
\text { (c) Explain how missing } \\
\text { data were addressed } \\
\text { (d) Cohort study - If } \\
\text { applicable, explain how } \\
\text { loss to follow-up was } \\
\text { addressed } \\
\text { Case-control study - If } \\
\text { applicable, explain how }\end{array}$ & p. 6 & \\
\hline
\end{tabular}




\begin{tabular}{|c|c|c|c|c|c|}
\hline & $\begin{array}{l}\text { Item } \\
\text { No. }\end{array}$ & STROBE items & $\begin{array}{l}\text { Location in } \\
\text { manuscript } \\
\text { where items are } \\
\text { reported }\end{array}$ & RECORD items & $\begin{array}{l}\text { Location in } \\
\text { manuscript } \\
\text { where items are } \\
\text { reported }\end{array}$ \\
\hline & & $\begin{array}{l}\text { matching of cases and } \\
\text { controls was addressed } \\
\text { Cross-sectional study - If } \\
\text { applicable, describe } \\
\text { analytical methods taking } \\
\text { account of sampling } \\
\text { strategy } \\
\text { (e) Describe any } \\
\text { sensitivity analyses }\end{array}$ & & & \\
\hline \multirow[t]{2}{*}{$\begin{array}{l}\text { Data access and } \\
\text { cleaning methods }\end{array}$} & & .. & & $\begin{array}{l}\text { RECORD 12.1: Authors should } \\
\text { describe the extent to which the } \\
\text { investigators had access to the } \\
\text { database population used to create } \\
\text { the study population. }\end{array}$ & p. 5 \\
\hline & & & & $\begin{array}{l}\text { RECORD 12.2: Authors should } \\
\text { provide information on the data } \\
\text { cleaning methods used in the study. }\end{array}$ & \\
\hline Linkage & & .. & & $\begin{array}{l}\text { RECORD 12.3: State whether the } \\
\text { study included person-level, } \\
\text { institutional-level, or other data } \\
\text { linkage across two or more } \\
\text { databases. The methods of linkage } \\
\text { and methods of linkage quality } \\
\text { evaluation should be provided. }\end{array}$ & p. 5 \\
\hline \multicolumn{6}{|l|}{ Results } \\
\hline Participants & 13 & $\begin{array}{l}\text { (a) Report the numbers of } \\
\text { individuals at each stage }\end{array}$ & p. 7 & $\begin{array}{l}\text { RECORD 13.1: Describe in detail } \\
\text { the selection of the persons included }\end{array}$ & p. 7 \\
\hline
\end{tabular}




\begin{tabular}{|c|c|c|c|c|c|}
\hline & $\begin{array}{l}\text { Item } \\
\text { No. }\end{array}$ & STROBE items & $\begin{array}{l}\text { Location in } \\
\text { manuscript } \\
\text { where items are } \\
\text { reported }\end{array}$ & RECORD items & $\begin{array}{l}\text { Location in } \\
\text { manuscript } \\
\text { where items are } \\
\text { reported }\end{array}$ \\
\hline & & $\begin{array}{l}\text { of the study ( } e . g ., \\
\text { numbers potentially } \\
\text { eligible, examined for } \\
\text { eligibility, confirmed } \\
\text { eligible, included in the } \\
\text { study, completing follow- } \\
\text { up, and analysed) } \\
\text { (b) Give reasons for non- } \\
\text { participation at each } \\
\text { stage. } \\
\text { (c) Consider use of a flow } \\
\text { diagram }\end{array}$ & & $\begin{array}{l}\text { in the study (i.e., study population } \\
\text { selection) including filtering based } \\
\text { on data quality, data availability and } \\
\text { linkage. The selection of included } \\
\text { persons can be described in the text } \\
\text { and/or by means of the study flow } \\
\text { diagram. }\end{array}$ & \\
\hline Descriptive data & 14 & $\begin{array}{l}\text { (a) Give characteristics of } \\
\text { study participants (e.g., } \\
\text { demographic, clinical, } \\
\text { social) and information } \\
\text { on exposures and } \\
\text { potential confounders } \\
\text { (b) Indicate the number of } \\
\text { participants with missing } \\
\text { data for each variable of } \\
\text { interest } \\
\text { (c) Cohort study - } \\
\text { summarise follow-up time } \\
\text { (e.g., average and total } \\
\text { amount) }\end{array}$ & p. 7,13 & & \\
\hline Outcome data & 15 & $\begin{array}{l}\text { Cohort study - Report } \\
\text { numbers of outcome }\end{array}$ & p. 7 & & \\
\hline
\end{tabular}




\begin{tabular}{|c|c|c|c|c|}
\hline & $\begin{array}{l}\text { Item } \\
\text { No. }\end{array}$ & STROBE items & $\begin{array}{l}\text { Location in } \\
\text { manuscript } \\
\text { where items are } \\
\text { reported }\end{array}$ & $\begin{array}{l}\text { Location in } \\
\text { manuscript } \\
\text { where items are } \\
\text { reported }\end{array}$ \\
\hline & & $\begin{array}{l}\text { events or summary } \\
\text { measures over time } \\
\text { Case-control study - } \\
\text { Report numbers in each } \\
\text { exposure category, or } \\
\text { summary measures of } \\
\text { exposure } \\
\text { Cross-sectional study- } \\
\text { Report numbers of } \\
\text { outcome events or } \\
\text { summary measures }\end{array}$ & & \\
\hline Main results & 16 & $\begin{array}{l}\text { (a) Give unadjusted } \\
\text { estimates and, if } \\
\text { applicable, confounder- } \\
\text { adjusted estimates and } \\
\text { their precision (e.g., 95\% } \\
\text { confidence interval). } \\
\text { Make clear which } \\
\text { confounders were } \\
\text { adjusted for and why they } \\
\text { were included } \\
\text { (b) Report category } \\
\text { boundaries when } \\
\text { continuous variables were } \\
\text { categorized } \\
\text { (c) If relevant, consider } \\
\text { translating estimates of } \\
\text { relative risk into absolute }\end{array}$ & p. 7,14 & \\
\hline
\end{tabular}


Appendix Table 2. RECORD Checklist

\begin{tabular}{|c|c|c|c|c|c|}
\hline & $\begin{array}{l}\text { Item } \\
\text { No. }\end{array}$ & STROBE items & $\begin{array}{l}\text { Location in } \\
\text { manuscript } \\
\text { where items are } \\
\text { reported }\end{array}$ & RECORD items & $\begin{array}{l}\text { Location in } \\
\text { manuscript } \\
\text { where items are } \\
\text { reported }\end{array}$ \\
\hline & & $\begin{array}{l}\text { risk for a meaningful time } \\
\text { period }\end{array}$ & & & \\
\hline Other analyses & 17 & $\begin{array}{l}\text { Report other analyses } \\
\text { done-e.g., analyses of } \\
\text { subgroups and } \\
\text { interactions, and } \\
\text { sensitivity analyses }\end{array}$ & N/A & & \\
\hline \multicolumn{6}{|l|}{ Discussion } \\
\hline Key results & 18 & $\begin{array}{l}\text { Summarise key results } \\
\text { with reference to study } \\
\text { objectives }\end{array}$ & p. 8 & & \\
\hline Limitations & 19 & $\begin{array}{l}\text { Discuss limitations of the } \\
\text { study, taking into account } \\
\text { sources of potential bias } \\
\text { or imprecision. Discuss } \\
\text { both direction and } \\
\text { magnitude of any } \\
\text { potential bias }\end{array}$ & p. 8 & $\begin{array}{l}\text { RECORD 19.1: Discuss the } \\
\text { implications of using data that were } \\
\text { not created or collected to answer } \\
\text { the specific research question(s). } \\
\text { Include discussion of } \\
\text { misclassification bias, unmeasured } \\
\text { confounding, missing data, and } \\
\text { changing eligibility over time, as } \\
\text { they pertain to the study being } \\
\text { reported. }\end{array}$ & p. 9 \\
\hline Interpretation & 20 & $\begin{array}{l}\text { Give a cautious overall } \\
\text { interpretation of results } \\
\text { considering objectives, } \\
\text { limitations, multiplicity of } \\
\text { analyses, results from } \\
\text { similar studies, and other } \\
\text { relevant evidence }\end{array}$ & p. 8 & & \\
\hline
\end{tabular}




\begin{tabular}{|c|c|c|c|c|c|}
\hline & $\begin{array}{l}\text { Item } \\
\text { No. }\end{array}$ & STROBE items & $\begin{array}{l}\text { Location in } \\
\text { manuscript } \\
\text { where items are } \\
\text { reported }\end{array}$ & RECORD items & $\begin{array}{l}\text { Location in } \\
\text { manuscript } \\
\text { where items are } \\
\text { reported }\end{array}$ \\
\hline Generalisability & 21 & $\begin{array}{l}\text { Discuss the } \\
\text { generalisability (external } \\
\text { validity) of the study } \\
\text { results }\end{array}$ & & & \\
\hline \multicolumn{6}{|c|}{ Other Information } \\
\hline Funding & 22 & $\begin{array}{l}\text { Give the source of } \\
\text { funding and the role of } \\
\text { the funders for the present } \\
\text { study and, if applicable, } \\
\text { for the original study on } \\
\text { which the present article } \\
\text { is based }\end{array}$ & p. 1 & & \\
\hline $\begin{array}{l}\text { Accessibility of } \\
\text { protocol, raw } \\
\text { data, and } \\
\text { programming } \\
\text { code }\end{array}$ & & .. & & $\begin{array}{l}\text { RECORD 22.1: Authors should } \\
\text { provide information on how to } \\
\text { access any supplemental } \\
\text { information such as the study } \\
\text { protocol, raw data, or programming } \\
\text { code. }\end{array}$ & p. 2 \\
\hline
\end{tabular}

